\title{
COMPARISON STUDY OF ANTIOXIDANT ACTIVITY FROM THREE BANANA LEAVES EXTRACTS
}

\author{
[Studi Perbandingan Aktivitas Antioksidan Tiga Jenis \\ Daun Pisang yang Berbeda]
}

\author{
Ratna Handayani ${ }^{1}{ }^{1}$, Kinkstie Fans ${ }^{1)}$, Titri Siratantri Mastuti ${ }^{1}$, and Dela Rosa ${ }^{2) *}$ \\ 1) Department of Food Technology, Faculty of Science and Technology, Universitas Pelita Harapan, Tangerang \\ ${ }^{2)}$ Department of Pharmacy, Faculty of Health Sciences, Universitas Pelita Harapan, Tangerang
}

Received May $8^{\text {th }} 2020 /$ Accepted March $23^{\text {rd }} 2021$

\begin{abstract}
Banana (Musa spp.) is mainly grown in the tropical and subtropical countries. Previous study reported that Musa spp. leaves had a potential antioxidant activity, but it was still rarely studied further. In this research, leaves of Musa balbisiana, Musa acuminate, and Musa paradisiaca were extracted using maceration method for 24 hours with three kinds of solvent having different polarities: ethanol (polar), ethyl acetate (semi polar), and hexane (nonpolar). The goal of this research was to compare and determine the stability of the antioxidant activity extracted from different Musa sp. leaves. The highest antioxidant activity is found from Musa balbisiana leaves extract with $\mathrm{IC}_{50}$ value $340.07 \pm 22.54 \mathrm{ppm}$ (hexane fraction). Correlation analysis between antioxidant activity, total phenolic content, and total flavonoid of the extracts cannot conclude that the active antioxidant substances in these three banana species leaves were from phenolic or flavonoid groups. This crude extract from Musa balbisiana was then subjected to various $\mathrm{pH}$ levels $(3.0,5.0,7.0$, and 9.0$)$ and temperatures $\left(50,70\right.$, and $\left.90^{\circ} \mathrm{C}\right)$ to determine the stability of its antioxidant activity. It is found that the best stability condition is at $\mathrm{pH} 3.0$ and temperature of $50^{\circ} \mathrm{C}$ with an increase of $63.1 \%$ in $\mathrm{IC}_{50}$, a decrease of $15.72 \%$ in total phenolics, and a decrease of $3.67 \%$ in total flavonoids as compared to before treatment.
\end{abstract}

Keywords: antioxidant, Musa acuminate, Musa balbisiana, Musa paradisiaca, phenolic

\begin{abstract}
ABSTRAK
Musa spp. umumnya tumbuh pada negara tropis dan subtropis. Penelitian terdahulu menyatakan bahwa daun Musa spp. memiliki potensi aktivitas antioksidan, namun masih terbatas penelitiannya. Pada penelitian ini, daun dari Musa balbisiana, Musa acuminata dan Musa paradisiaca diekstrak melalui metode maserasi selama 24 jam dengan menggunakan tiga jenis pelarut dengan polaritas berbeda: etanol (polar), etil asetat (semi-polar) dan heksana (non-polar). Tujuan dari penelitian yang dilakukan adalah untuk membandingkan dan menentukan stabilitas aktivitas antioksidan ekstrak daun Musa sp. berbeda. Nilai antioksidan tertinggi didapatkan pada ekstrak kasar daun Musa balbisiana dengan nilai IC $_{50}$ sebesar $340,07 \pm 22,54$ ppm (fraksi heksana). Analisa korelasi antara aktivitas antioksidan, jumlah total kandungan fenolik, dan jumlah total flavonoid dari ekstrak yang ada, tidak dapat menyimpulkan bahwa senyawa antioksidan pada daun ketiga spesies pisang ini berasal dari grup senyawa fenolik atau flavonoid. Ekstrak kasar Musa balbisiana diberi perlakuan tingkat $\mathrm{pH}$ (3,0; 5,0; 7,0; dan 9,0) dan suhu (50, 70, dan $\left.90^{\circ} \mathrm{C}\right)$ yang berbeda untuk menentukan stabilitas aktifitas antioksidan. Kondisi stabil terbaik dicapai pada pH 3,0 dengan suhu $50^{\circ} \mathrm{C}$, dengan peningkatan $I C_{50}$ sebesar $63,1 \%$, penurunan total fenolik sebesar $15,72 \%$, serta penurunan total flavonoid sebesar $3,67 \%$ dibandingkan dengan sebelum perlakuan.
\end{abstract}

Kata Kunci: antioksidan, fenolik, Musa acuminata, Musa balbisiana, Musa paradisiaca

\footnotetext{
The manuscript has been presented in The $16^{\text {th }}$ Asean Food Conference 2019 , October $15^{\text {th }}-18^{\text {th }} 2019$, Bali-Indonesia
} *Corresponding Author: E-mail: dela.rosa@uph.edu 


\section{INTRODUCTION}

Indonesia is a tropical country which has many natural resources, including in the field of horticulture. The most important and widely planted fruit in Indonesia is banana (Vezina et al., 2016). In the world, banana is indeed one of the most important crops: it is number four after rice, maize, and corn (Venkataramana et al., 2015). Banana is even a major staple crop in many regions in Asia and Africa. There are several species of banana, but the most commercial and widely consumed are usually from species Musa acuminata and Musa balbisiana. Hybrid of those two is Musa paradisiaca (Sunaryo et al., 2017).

Each part of banana plant have some benefits for human. Banana fruit is a good prebiotic to stimulate the growth of beneficial intestinal bacteria since it contains fructose, xylose, galactose, glucose and mannose (Karuppiah and Mustaffa, 2013). Corms of Musa paradisiaca show antihelmintic activities (Venkatesh et al., 2013). The stem can be used to heal nervous affectations, such as epilepsy and hysteria, also to heal dysentery and diarrhea (Debabandya et al., 2010). Banana leaf is commonly used to wrap some food because it can give specific taste and flavor (Kumar et al., 2012). Many researches have been done to test the activity of the banana leaf. A study by Sahaa et al. (2013) found that Musa sapietum leaf has antimicrobial and antioxidant activity. Musa acuminata and Musa balbisiana leaf extracts using ethyl acetate contain 1,2benzenedicarboxylic acid, bis(2-ethylexyl) ester which has antimicrobial and antioxidant activity (Mastuti and Handayani, 2014). Musa paradisiaca leaf is indicated has a potential anti-diabetic property (Kappel et al., 2013). Despite all the research on banana, it is not yet known which banana leaf extract has the highest antioxidant activity. Besides that, the stability of antioxidant in banana leaf is not yet known.

Antioxidants are compounds which can inhibit the chemical reaction called oxidation. Oxidation may damage cells since one of the outputs of this reaction are free radicals. Free radicals are dangerous because they may initiate chain reactions which lead to cell damage. Synthetic antioxidants are prohibited and limited nowadays; meanwhile natural antioxidants are developed because they have fewer side effects. Antioxidants can help to prevent diseases in human, especially degenerative diseases (Rani, 2017). The purpose of this research was to compare and determine the stability of antioxidant activity extracted from the leaves of three banana species: Musa balbisiana, Musa acuminata, and Musa paradisiaca.

\section{MATERIALS AND METHODS}

\section{Materials}

Samples of Musa balbisiana, Musa acuminata, and Musa paradisiaca were obtained from a banana plantation located in Budi Indah Regency, Tangerang, Indonesia. The leaves were taken from the banana tree which was more than twelve months old. Folin-Ciocalteu reagent, gallic acid, DPPH (2,2Dipheynil-1-Picrylhidrazyl), aluminum chloride, sodium carbonate (Merck, Germany) and Quercetin (Sigma Aldrich, USA).

\section{Extraction of banana leaves}

The leaf samples of three kinds of banana (Musa acuminata, Musa balbisiana, and Musa paradisiaca) were washed carefully and dried using cabinet dryer at $60^{\circ} \mathrm{C}$ for 24 hours, continued with blending them with dry blender to make theirs size smaller. Each kind of banana leaf was weighted and portioned to about $60 \mathrm{~g}$, and then macerated for 24 hours using $240 \mathrm{~mL}$ of hexane as solvent. The result of this maceration was referred to as hexane fraction. Consecutive maceration of the dried samples was done for 24 hours using $240 \mathrm{~mL}$ of ethyl acetate as a solvent, producing ethyl acetate fraction. The last maceration of the dried samples using $240 \mathrm{~mL}$ of ethanol was done to obtain ethanol fraction. The solvent in all fractions was evaporated using rotary evaporator (R-210 Buchi, Switzerlad) at $60^{\circ} \mathrm{C}$. All extraction processes in this research were done twice. For each extract, the absorbance measurements for antioxidant assay, total phenolics and total flavonoids were done 3 times respectively to minimize the error of absorbance measurements.

\section{Antioxidant assay}

Antioxidant assay was done using DPPH (2,2Dipheynil-1-Picrylhidrazyl) (Nahak and Sahu, 2011). Sample was taken $0.8 \mathrm{~mL}$ and mixed with DPPH 0.2 $\mathrm{mM}$, then homogenized using vortex. It was followed by 30 minute-incubation of the mixture in a dark room. Absorbance value was then measured at wavelength $517 \mathrm{~nm}$ using UV-Vis spectrophotometer (Genesys 20, Thermo Scientific, USA). One milliliter of DPPH $0.2 \mathrm{mM}$ was added with $0.8 \mathrm{~mL}$ of ethanol as control. For the blank, $1.8 \mathrm{~mL}$ of ethanol was used.

\section{Determination of total phenolic content (TPC)}

TPC was performed based on a method by Aryal et al. (2019). Folin and Ciocalteu reagent was used. $0.5 \mathrm{~mL}$ of sample and $2.5 \mathrm{~mL}$ of Folin solution $(1: 10 \mathrm{v} / \mathrm{v})$ were mixed and homogenized. After 5 minutes, the mixture was added with $2 \mathrm{~mL}$ of saturated solution $(7.5 \% \mathrm{w} / \mathrm{v})$ of sodium carbonate and homogenized. Light was prevented to reach the resulting mixture for 30 minutes. The absorbance 
was measured using UV-Vis spectrophotometer at wavelength of $760 \mathrm{~nm}$. The external calibration was done using different concentration of gallic acid (10, $20,30,40,50,60,70,80,90$, and $100 \mathrm{ppm})$. The total phenolic content obtained was presented in gallic acid equivalents (GAE/g) (dry based).

\section{Determination of total flavonoid content (TFC)}

TFC was done based on Lamien-Meda et al. (2008). One milliliter of aluminum chloride was added to $1 \mathrm{~mL}$ of sample and the mixture was homogenized and put in the dark room for 10 minutes. Absorbance was determined using UV-Vis spectrophotometer at wavelength of $415 \mathrm{~nm}$. As blank, aluminum chloride solution was used. Quercetin was used to prepare the standard calibration curve. Concentrations of quercetin used were $5,10,15,20,25$, and 30 ppm. The results obtained were expressed as $\mathrm{mg}$ quercetin equivalent $(\mathrm{QE}) / \mathrm{g}$ of dried plant material.

\section{Stability of antioxidant activity}

To test the stability of antioxidant activity, the fraction with the highest antioxidant activity was subjected to several temperatures $(50,70$, and $90^{\circ} \mathrm{C}$ ) and different $\mathrm{pH}$ levels $(3,5,7,9)$. For each combination of temperature and $\mathrm{pH}$ level, the $\mathrm{IC}_{50}$ of the antioxidant activity, total flavonoids and total phenolics contents were measured.

\section{RESULTS AND DISCUSSION}

\section{Yield of the extract}

The average yields of the banana leaf extracts in this research are in the range $1.22-4.23 \%$. The yield is influenced by the banana species and the solvent used, as can be seen in Table 1. Two-way ANOVA test shows that the yields for different banana species and different solvents are statistically different $(P<0.05)$. As can be seen in Table 1 , ethanol produces more yield compared to other solvents. This result supports the research done by Karuppiah and Mustaffa (2013), which also finds that polar solvents produce more banana leaf extract yield than semi-polar and non-polar solvents. It can be concluded therefore that most chemical compounds contained in the banana leaf are polar. The banana species that has the most polar compounds in its leaves is Musa paradisiaca (Table 1 ), but this species has less semi-polar and nonpolar compounds compared to the other two banana species.

Table 1. Yield of the leaf extract of different banana species and different solvents

\begin{tabular}{ccc}
\hline Species & Fraction & Yield (\%) \\
\hline Musa acuminata & Hexane & $1.42 \pm 0.02$ \\
& Ethyl Acetate & $2.06 \pm 0.01$ \\
& Ethanol & $3.50 \pm 0.02$ \\
\hline Musa balbisiana & Hexane & $1.84 \pm 0.04$ \\
& Ethyl Acetate & $2.47 \pm 0.01$ \\
& Ethanol & $3.75 \pm 0.03$ \\
\hline Musa paradisiaca & Hexane & $1.22 \pm 0.05$ \\
& Ethyl Acetate & $1.97 \pm 0.02$ \\
& Ethanol & $4.23 \pm 0.01$ \\
\hline
\end{tabular}

\section{Antioxidant activity}

Antioxidant activity of banana leaf extract is affected by banana species and the solvents used (Table 2). Statistical analysis results using Two-way ANOVA show that all entries are statistically different $(P<0.05)$. From Table 2, hexane fraction of Musa balbisiana leaf extract has the least $\mathrm{IC}_{50}$ of $340.07 \pm$ $22.54 \mathrm{ppm}$. It means that this banana species has the highest antioxidant activity.

In average, the leaf of Musa balbisiana has a lower $I_{50}$ (higher antioxidant activity) compared to the other banana species. The lowest antioxidant activity is shown by Musa acuminata. This result is supported by Karuppiah and Mustaffa (2013) who also find out that the antioxidant activity of Musa acuminata leaf is lower than the leaf of Musa paradisiaca.

Table 2. $\mathrm{IC}_{50}$ of antioxidant activity, total flavonoid content, and total phenolic content of banana leaf extract for different banana species and solvents used

\begin{tabular}{|c|c|c|c|c|}
\hline Species & Fraction & $\mathrm{IC}_{50}(\mathrm{ppm})$ & $\begin{array}{c}\text { Total Phenolic (mg } \\
\text { GAE/g sample) }\end{array}$ & $\begin{array}{c}\text { Total Flavonoid (mg } \\
\text { QE/g sample) }\end{array}$ \\
\hline \multirow[t]{3}{*}{ Musa acuminata } & Hexane & $958.45 \pm 63.64$ & $7.33 \pm 0.05$ & $59.03 \pm 0.63$ \\
\hline & Ethyl Acetate & $779.26 \pm 28.12$ & $9.71 \pm 0.01$ & $125.99 \pm 0.21$ \\
\hline & Ethanol & $937.69 \pm 30.06$ & $11.06 \pm 0.05$ & $46.08 \pm 0.04$ \\
\hline \multirow[t]{3}{*}{ Musa balbisiana } & Hexane & $340.07 \pm 22.54$ & $11.45 \pm 0.01$ & $72.30 \pm 0.21$ \\
\hline & Ethyl Acetate & $780.95 \pm 12.32$ & $12.46 \pm 0.02$ & $138.38 \pm 0.63$ \\
\hline & Ethanol & $579.26 \pm 14.66$ & $16.20 \pm 0.04$ & $89.26 \pm 0.42$ \\
\hline \multirow[t]{3}{*}{ Musa paradisiaca } & Hexane & $933.49 \pm 6.74$ & $8.14 \pm 0.02$ & $69.94 \pm 0.21$ \\
\hline & Ethyl Acetate & $515.02 \pm 14.63$ & $12.74 \pm 0.02$ & $111.83 \pm 1.46$ \\
\hline & Ethanol & $856.06 \pm 7.65$ & $14.75 \pm 0.01$ & $41.62 \pm 0.21$ \\
\hline
\end{tabular}




\section{Total phenolic content}

Results for total phenolic content can be seen in Table 2. Two-way ANOVA test shows that both banana species and the solvent type significantly influence $(P<0.05)$ total phenolic content of banana leaf extract. It can be seen in Table 2 that Musa balbisiana leaf shows in general higher total phenolic content compared to the other two banana species. The highest total phenolic content is obtained for ethanol fraction of Musa balbisiana leaf. In general, solvents that are more polar tend to produce higher phenolic content. The ethanol fraction in all banana species has the highest phenolic content. This is because most phenolic compounds are polar, and therefore can be easier extracted using polar solvent (Haminiuk et al., 2014). Comparison between the lowest $\mathrm{IC}_{50}$ and the highest total phenolic content cannot conclude that the antioxidant compound in banana leaf of the three species investigated is from phenolic group. Further research is needed to elucidate the bioactive compound(s).

\section{Total flavonoid content}

Two-way ANOVA test on the entries of Table 2 show that the total flavonoid content of banana leaf extract is influenced significantly $(P<0.05)$ by banana species and type of extraction solvents. Here the highest total flavonoid is shown by ethyl acetate fraction of the leaf extract of Musa balbisiana. Unlike total phenolic content, the solvent that produces the highest total flavonoid content is ethyl acetate, not ethanol. This might be due to the composition of the flavonoid compounds in banana leaves, which are not all polar compounds. By comparing the fraction between the highest total flavonoid content and the one with the lowest $I C_{50}$, it cannot be concluded that the bioactive com-pound with antioxidant activity in the leaves of the three investigated banana species is from flavonoid group. However, further research is needed to confirm this finding.

\section{Stability of the antioxidant activity}

The result of the stability test for hexane fraction of Musa balbisiana leaf extract can be seen in Table 3. This fraction is chosen because it shows the highest antioxidant activity with $\mathrm{IC}_{50}$ of $340.07 \pm$ $22.54 \mathrm{ppm}$. In general, it can be seen that the higher the temperature, the higher the $I_{50}$ of the leaf extract will be. Also, the higher the $\mathrm{pH}$ level, the higher also the $\mathrm{IC}_{50}$ of the leaf extract will be. The changes are quite significant: for $\mathrm{pH} 3.0$ and temperature $50^{\circ} \mathrm{C}$ : there is an increase of $63.1 \%$ of $\mathrm{IC}_{50}$ compared to before treatment. As the $\mathrm{pH}$ level and temperature increase even more, the increase of $\mathrm{IC}_{50}$ is even larger. This means that the antioxidant activity is weakening as the $\mathrm{pH}$ level and temperature increase. The bioactive compound responsible for the antioxidant activity is most likely not resistant to high temperature and high $\mathrm{pH}$ level. The $\mathrm{pH}$ level of banana leaf extract before the stability test treatment is 2.1 which is indeed lower than the tested $\mathrm{pH}$ level. The $\mathrm{IC}_{50}$ of the banana leaf extract before the stability test treatment is also lower than after the stability tests.

Other researchers have also observed that antioxidant activity indeed depends on temperature. There is an optimum temperature for the antioxidant to be active (Settharaksa et al., 2012). Another research by Xie et al. (2018) also explains that antioxidant activity will increase as $\mathrm{pH}$ level decreases, since low $\mathrm{pH}$ level will help to regenerate the antioxidant compound.

Table 3. Stability of $\mathrm{IC}_{50}$, total phenolic content and total flavonoid content of hexane fraction of Musa balbisiana leaf extract with respect to different temperatures and $\mathrm{pH}$ levels

\begin{tabular}{ccccc}
\hline $\mathrm{pH}$ & Temperature $\left({ }^{\circ} \mathrm{C}\right)$ & $\mathrm{IC} 50(\mathrm{ppm})$ & $\begin{array}{c}\text { Total Phenolic } \\
(\mathrm{mg} \mathrm{GAE} / \mathrm{g} \text { sample })\end{array}$ & $\begin{array}{c}\text { Total Flavonoid } \\
(\mathrm{mg} \text { QE/g sample) }\end{array}$ \\
\hline 3.0 & 50 & $554.66 \pm 2.73$ & $9.65 \pm 0.05$ & $69.65 \pm 0.10$ \\
& 70 & $647.87 \pm 6.65$ & $9.19 \pm 0.07$ & $63.30 \pm 0.31$ \\
& 90 & $860.43 \pm 17.51$ & $8.50 \pm 0.09$ & $54.89 \pm 0.10$ \\
\hline 5.0 & 50 & $1190.88 \pm 23.68$ & $7.89 \pm 0.03$ & $60.65 \pm 1.10$ \\
& 70 & $1394.86 \pm 22.89$ & $7.52 \pm 0.06$ & $56.08 \pm 0.10$ \\
& 90 & $1591.24 \pm 12.45$ & $6.81 \pm 0.03$ & $45.61 \pm 0.01$ \\
\hline 7.0 & 50 & $2440.50 \pm 25.83$ & $5.30 \pm 0.10$ & $48.78 \pm 0.16$ \\
& 70 & $2615.52 \pm 12.74$ & $4.50 \pm 0.07$ & $43.98 \pm 0.10$ \\
\hline 9.0 & 90 & $2643.11 \pm 10.48$ & $3.57 \pm 0.06$ & $39.48 \pm 0.05$ \\
& 50 & $3886.29 \pm 51.66$ & $4.19 \pm 0.10$ & $45.46 \pm 0.10$ \\
& 70 & $4240.27 \pm 28.67$ & $3.29 \pm 0.11$ & $40.52 \pm 0.05$ \\
\hline
\end{tabular}


Table 3 also shows that phenolic and flavonoid compounds in the banana leaf extract tend to disintegrate as the $\mathrm{pH}$ level and temperature increase. When the $\mathrm{pH}$ level is 3.0 and the temperature is $50^{\circ} \mathrm{C}$, there is a decrease of $15.72 \%$ for total phenolics content, and a decrease of $3.67 \%$ for total flavonoid content compared to before treatment. The decrease in total phenolics and flavonoid content are getting larger as $\mathrm{pH}$ and temperature increase. The decrease in total phenolic content as the $\mathrm{pH}$ level increases is also observed in Allium cepa and Piper crocatum (Machavarapu et al., 2013; Dewandari et al., 2013), so it seems to be a common trend. Temperature increase has also been observed to lower the total phenolic content (Settharaksa et al., 2012). Another research has also observed the decrease in total flavonoid content as temperature increases (Rahmawati et al., 2013).

\section{CONCLUSION}

This research shows that Musa balbisiana leaf extract contains the most active antioxidant, shown by the lowest $\mathrm{IC}_{50}$, and the highest phenolic and flavonoid content, when compared to Musa acuminata and Musa paradisiaca. The highest antioxidant activity of extract from Musa balbisiana leaf is obtained in the hexane fraction with $\mathrm{IC}_{50} 340.07 \pm$ $22.54 \mathrm{ppm}$. The antioxidant activity, phenolic and flavonoid content of the hexane fraction of Musa balbisiana leaf extract are not stable for higher temperature and higher $\mathrm{pH}$ level. All parameters decrease as temperature and $\mathrm{pH}$ increase.

\section{ACKNOWLEDGEMENT}

Authors would like to thank Quality Control Laboratory and Food Processing Laboratory at Universitas Pelita Harapan for providing facilities needed to do this research.

\section{REFERENCES}

Aryal S, Baniya MK, Danekhu K, Kunwar P, Gurung R, Koirala N. 2019. Total phenolic content, flavonoid content and antioxidant potential of wild vegetables from western Nepal. Plants 8: 96. DOI:10.3390/plants8040096.

Debabandya M, Sabyasachi M, Namrata S. 2010. Banana and its by-products utilization: an overview. J Sci Ind Res 69: 323-329.
Dewandari KT, Sri Y, Sedarnawati Y. 2013. Ekstraksi dan karakterisasi nanopartikel ekstrak sirih merah (Piper crocatum). J Penelitian Pascapanen Pertanian 10: 65-71.

Haminiuk CWI, Plata-Oviedo MSV, de Mattos G, Carpes ST, Branco IG. 2014. Extraction and quantification of phenolic acids and flavonols from Eugenia pyriformis using different solvents. J Food Sci Technol 51: 2862-2866. DOI: 10.1007/s13197-012-0759-z. .

Kappel VD, Cazarolli LH, Pereira DF, Postal BG, Madoglio FA, Buss ZD, Reginatto FH, Silva FRMB. 2013. Beneficial effects of banana leaves (Musa paradisiaca) on glucose homeostasis: multiple sites of action. Revista Brasileira de Farmacognosia 23: 706-715. DOI: 10.159 0/S0102-695X2013005000062.

Karuppiah P, Mustaffa M. 2013. Antibacterial and antioxidant activities of Musa sp. leaf extracts against multidrug resistant clinical pathogens causing nosocomial infection. Asian Pacific J Tropical Biomed 3: 737-742. DOI: 10.1016/S22 21-1691(13)60148-3.

Kumar KPS, Debjit B, Duraivel S, Umadevi M. 2012. Traditional and medicinal uses of banana. J Pharm Phytochem 1: 57-70.

Machavarapu M, Manoj KS, Meena V. 2013. Optimization of physicochemical parameters for the extraction of flavonoids and phenolic components from the skin of Allium cepa. Int $\mathrm{J}$ Innov Res Sci Eng Technol 2: 3125-3129.

Mastuti TS, Handayani R. 2014. Senyawa Penyusun Ekstrak Ethyl Asetat Dari Daun Pisang Batu dan Ambon Hasil Distilasi Air. Prosiding Seminar Nasional Sains dan Teknologi ke- 5 Fakultas Teknik, Universitas Wahid Hasyim, Semarang.

Nahak GS, Sahu RK. 2011. Evaluation of antioxidant activity in ethanolic extracts of five curcuma species. Int Res J Pharm 2: 243-248.

Rahmawati F, Dwiyanti G, Sholihin H. 2013. Kajian aktivitas antioksidan produk olahan buah jambu biji merah (Psidium guajava L.). J Sains Teknol Kimia 4: 1-8.

Rani K. 2017. Role of antioxidants in prevention of diseases. J Appl Biotechnol Bioeng 4: 495-496.

Sahaa RK, Srijian A, Syed Sohidul HS, Priyanka R. 2013. Medicinal activities of the leaves of Musa sapientum var. sylvesteris in vitro. Asian Pacific J Tropical Biomed 3: 476-482. DOI: 10.1016/ S2221-1691(13)60099-4. 
Settharaksa S, Jongjareonrak A, Hmadhlu P, Chansuwan W, Siripongvutikorn S. 2012. Flavonoid, phenolic contents and antioxidant properties of Thai hot curry paste extract and its ingredients as affected of $\mathrm{pH}$, solvent types and high temperature. Int Food Res J 19: 1581-1587.

Sunaryo W, Nurhasanah, Rahman, Sugiarto A. 2017. Identification and characterization of talas banana, a superior local cultivar from East Kalimantan (Indonesia), based on morphological and agronomical characters. Biodiversitas 18: 1414-1423.

Venkataramana RK, Sampangi-Ramaiah MH, Ajitha R, Khadke GN, Chellam V. 2015. Insights into Musa balbisiana and Musa acuminata species divergence and development of genic microsa- tellites by transcriptomics approach. Plant Gene 4: 78-82. DOI: 10.1016/j.plgene.2015.09.007.

Venkatesh, Krishna V, Kumar KG, Pradeepa K, Kumar SRS, Vijay K. 2013. Anthelmintic Activity of Musa paradisiaca (L.) cv. Puttabale. Int J Pharm Sci Drug Res 5: 67-69.

Vezina A, Claesens G, Van den Bergh I. 2016. Banana diversity in Indonesia. http://www. promusa.org/Banana+diversity+in+Indonesia, 2019 [ June $3^{\text {rd }}$ 2019].

Xie Y, Li X, Chen J, Deng Y, Lu W, Chen D. 2018. $\mathrm{PH}$ effect and chemical mechanisms of antioxidant higenamine. Molecules 23: 2176. DOI: 10.3390/molecules23092176. 